\title{
Thoughts on Competitiveness and Integrated Industrial Policy: A Field of Mutual Convergences
}

\author{
Charis Vlados ${ }^{1,2} \&$ Dimos Chatzinikolaou ${ }^{1}$ \\ ${ }^{1}$ Department of Economics, Democritus University of Thrace, Komotini, Greece \\ ${ }^{2}$ School of Business, University of Nicosia, Nicosia, Cyprus \\ Correspondence: Dimos Chatzinikolaou, Department of Economics, Democritus University of Thrace, Komotini, \\ Greece.
}

Received: April 13, 2020

Accepted: May 20, 2020

Online Published: June 15, 2020

doi:10.5430/rwe.v11n3p12

URL: https://doi.org/10.5430/rwe.v11n3p12

\begin{abstract}
Competitiveness and industrial policy seem to play a critical role in the development and mutation of different spatialized socio-economic systems. This article aims to review the literature on these two concepts and suggest a novel theoretical framework. First, we identify that, in the relevant literature, industrial policy acquires progressively a repositioned content, described as a new, holistic, multidimensional, or integrated policy that can help create and sustain the competitiveness of the firms, industries, localities, nations, or other socio-economic agglomerations. In this context, we explore the form of an actual integrated industrial policy and propose the theoretical framework of the competitiveness web, in which the co-evolution of micro-meso-macro levels are explored, by placing the dynamics of business innovation at the dialectic center of the overall developmental process. This integrated industrial policy to strengthen competitiveness must also be able to promote innovation in the different local and regional ecosystems and, therefore, we conceive a policy mechanism in the form of the Institutes of Local Development and Innovation (ILDI). The primary purpose of these institutes is to diagnose and strengthen the Stra.Tech.Man physiology (strategy-technology-management synthesis) of the local socio-economic organizations. We believe that this new approach to the integrated industrial policy to strengthen the local competitiveness can contribute to facilitating the adaptation of the socio-economic systems, and especially the less dynamic and developed, to the new emerging challenges of the crisis and restructuring of globalization in the pandemic era.
\end{abstract}

Keywords: competitiveness and industrial policy, multilevel competitiveness, integrated industrial policy, socio-economic development, Competitiveness Web, Institutes of Local Development and Innovation

\section{Introduction}

The concept of competitiveness involves a multitude of analytical elements for the study of socio-economic development since it describes how the socio-economic actors survive, adapt and innovate in conditions of competition (Herciu et al., 2011). Some forms that competitiveness receives in today's theory are firm, industrial, regional, or national competitiveness and, in this sense, all levels of space are "organisms" that compete to survive in the continually transforming conditions of their internal and external environment (Balkytė \& Tvaronavičiené, 2010). The Global Competitiveness Report (2017), a prominent yearly report that classifies and ranks the competitiveness of nations, defines competitiveness as the sum of institutions and policies that determine an economy's level of productivity that, in turn, determines how prosperous this economy can be. However, according to Garelli (2006), competitiveness is a concept that goes beyond productivity since it includes the aggregation of physical assets, wealth and overall power, and, in this sense, competitiveness is about benchmarking because it can tell the differences in performance between nations or companies in specific timeframes.

It seems that competitiveness is a more profound concept than productivity since it constitutes a critical development and underdevelopment dimension of the socio-economic systems at all their structured micro, meso and macro levels (Dopfer et al., 2004). The problem is that, usually, national policies for strengthening competitiveness are exhausted in the industrial aspect of the phenomenon, attempting to subsidize specific segments of their national productive system and firms of oligopolistic character. In this practice of industrial policy, government intervention aims to foster the productive potential of an industrial-spatial entity by supporting specific sectors of the national economy and thus improving the overall competitiveness of the national industry (Naudé, 2010). 
Some scholars recognize a broader role of a new structural and integrated industrial policy that aims to eliminate the obstacles that hinder economic development (Chang, 2010; Robinson, 2009; Rodrik, 2008). From a structuralist perspective (Fischer, 2015), industrial policy attempts to alter the productive mainstays of specific sectors and promote the overall economic growth of the national socio-economic system (Mbate, 2016). Nevertheless, even in this structural approach, industrial policy does not target the multilevel strengthening of competitiveness, something which is evident for authors like Peneder (2017), Vlados and Chatzinikolaou (2020) and some others (for example, Falck et al., 2011; Lall, 2004) who suggest that industrial policy is a more broad concept that unifies all levels of space.

Reviewing prior studies on competitiveness and industrial policy, we identified a gap in the literature: as it seems, no study has attempted to examine their mutual conceptual evolution. Therefore, we considered that the following questions could have significant implications for future research on the subject:

- If competitiveness means how the socio-economic systems and actors at all levels improve their adaptive and innovative potential and industrial policy acquires a more integrated and multilevel character gradually, then how does the literature deal with this connection? What does the literature suggest in conceptual terms, and what are some directions of synthesis?

- Can we build upon this synthesis a theoretical framework of a new industrial policy that enhances competitiveness?

In more formal terms, our final goal is, after studying a portion of the literature that examines in combination these two concepts, to find out how it defines them so that we can counter-propose a new and synthesizing conceptual model. One of the methodologies for achieving such a form of bibliographic analysis is the integrative literature review (Snyder, 2019), which we intend to use for this study. The integrative literature review has as a purpose to criticize and synthesize the existing literature by setting broad or narrow research questions (broad, in our case). Its research strategy is usually articulated in a non-systematic way, while it may include and other sources besides scientific articles. Its evaluation remains qualitative, and it contributes to the scientific domain of analysis by providing a taxonomy or classification of the literature or a new theoretical model or framework (the latter is also the final goal of our study).

Sub-sections 2.1 and 2.2 will explore some evolving trends in the analysis of competitiveness and industrial policy, while 2.3 will focus on specific bibliography that combines these two terms explicitly. The derived definitions will lead us in section 3 to formulate a repositioned and synthesizing approach, capable of producing a new explanatory framework. In the concluding section 4, we will recap the research by also discussing limitations and future directions.

\section{Literature Review}

As we have presented in the introduction, both competitiveness and industrial policy are two concepts that take on several interpretations and, sometimes, contrasting perspectives. The purpose of this segment is to analyze some debates in competitiveness and industrial policy, leading us to explore how these two terms are treated in relevant bibliography with a co-evolutionary perspective.

\subsection{Multiple Perceptions and Evolving Trends in the Analysis of Competitiveness}

Since the 1970s, when the competitiveness debate began to emerge, multiple definitions have been proposed. For example, for Bobba et al. (1971), competitiveness means the capability of nations, regions and firms to create new wealth, while for Scott and Lodge (1985), national competitiveness means the capacity of a nation to generate and trade products and services internationally. In other definitions, D'Andrea (1992) observes in national competitiveness the capacity to produce the products that match the standards of international competition while retaining a prosperous domestic economy, while Ajitabh and Momaya (2004) consider competitiveness as the share of a firm or industry in the competitive market.

Therefore, multiple factors affect (or affected by) competitiveness, depending on the perspective and the specific subsystem under analysis (Pollak et al., 2018). Siudek and Zawojska (2014) classify competitiveness by suggesting the existence of various levels of competitiveness, such as firm, local, industrial, regional, national, and supranational levels of competitiveness. In this regard, competitiveness is a force beyond a single socio-economic subsystem.

However, a significant critique by Krugman (1994) posed another issue. Krugman suggested that nations do not compete in the sense that firms do since they cannot halt their operation. In our perspective, however, the argument of Krugman detours the evolutionary and institutional dimensions of development in which it is argued that even 
though institutions create the conditions for the establishment of rules and norms that remain unchanged for long periods, these do change through institutional innovations (Raffaelli \& Glynn, 2015). According to Acemoglu and Robinson (2012), these institutional variations involve the historical weaving and establishment of inclusive or extractive institutions that change only slowly in the history, although dramatic events can occur that alter the institutional physiognomy radically. Therefore, the critique towards competitiveness as another meaning of productivity for the firms solely, as suggested by Krugman, does not seem to have such interpretive power since also all institutions are "organisms" that evolve (Hodgson, 1994). Krugman himself seems to have subsequently revised to some degree his previous view on competitiveness, which is indeed popular around the competitiveness debate (P. Krugman, 1996).

Competitiveness nowadays bears multilevel significance and implications (according to Esser et al., 2013, competitiveness is a systemic notion), as it is not enough to study the productivity of firms or to classify nations according to the industries they host like in a "Porter's diamond" approach (Porter, 1990). Porter's approach has also been the subject of criticism since it appears to circumvent the global element of competitive advantage creation by presenting national competitiveness as the industrial outcome of demand, supply, firm strategy and related industries, including the external determinants of chance and government (Cho \& Moon, 2000; Dunning, 1993; Vlados, 2019b).

Overall, through the evolving trends in the field of competitiveness, we could end up with the following definition: the concept of competitiveness means a socio-economic actor's ability to perform better than other competitive actors within the multilevel socio-economic environment that hosts this competitive activity.

\subsection{Multiple Perceptions and Evolving Trends in the Analysis of Industrial Policy}

A widespread practice of strengthening competitiveness is nowadays industrial policy, which is also studied in the context of various theoretical perspectives. The practice of industrial policy emerged towards the end of the $19^{\text {th }}$ century as a lever for empowering specific industries, a form of intervention that was followed and is still activated within many national socio-economic systems (Irwin, 2004).

Some theoretical contributions in this direction of favoring specific segments of the economy are indicative. According to OECD (1975), industrial policy concerns the aspects of industrial growth and efficiency. Tyson and Zysman (1983) consider industrial policy as the means to solve problems at specific industries while, in a similar orientation, Krugman and Obstfeld (1991) as an attempt by the government to move resources in sectors that are presented to have significant growth potential.

These approaches continue the early post-war notions of strengthening specific sectors. In the early post-war years specifically, where the Fordist accumulation regime for the different national entities lead to unprecedented growth in industry (Boyer \& Durand, 1993), industrial policy was focused on the immediate intervention and correction of market imbalances by providing subsidies and direct reinforcement to "national champions" (OECD, 2009). From the appearance of market liberalization policies and the multi-nationalization of companies in the mid-1970s, industrial policy started to focus more on the logic of the "invisible hand" of the market (Yao, 1988), where markets are supposed to regulate themselves.

Contrary to these limitative approaches, industrial policy acquires a more dynamic content and perspective gradually. The actual objective of industrial policy in a globalized economy is primarily to attract foreign investment and to create an environment conducive to this direction (Pack, 2000). The measures taken by the industrial policy must be horizontal, not reinforcing specific firms or sectors selectively (Krueger, 1990; Pack, 1993). An industrial policy for the $21^{\text {st }}$ century is one that focuses on restructuring policies that can favor complex activities irrespectively of their loci or industry (Rodrik, 2004). According to Pack and Saggi (2006), this policy must be a selective intervention that aims at altering the productive structure of the economy, while Warwick (2013) suggests that a "soft" form of this policy must aim to co-ordinate strategic priorities between the government and the industry.

In conclusion, industrial policy perception and practice appear to be transforming over time. From the industrial policy as a lever to growth for specific sectors (vertical conception), and the provision of framework conditions for the stability and growth of the national socio-economic system (horizontal conception), industrial policy today seems to change towards the direction of recognizing the many levels of governance in modern socio-economic systems (say, diagonal conception; Torfing et al., 2012).

\subsection{Combined Evolution Between Industrial Policy and Competitiveness}

From examining the evolutionary trends of the concepts of industrial policy and competitiveness, we can perceive that they are gaining an increasingly integrated and multileveled content. So far, however, we have not seen how these are combined explicitly in international literature and practice. To this end, we have attempted to put in 
chronological order and study the main points of a portion of the literature that combines these two terms directly. Table 1 presents such focal points from publications containing both concepts in their title. These studies were identified via the Scopus database after searching the terms competitiveness and industrial policy in the title of the publication. The search showed 23 records starting from 1976 to 2017 from which we removed four non-English and one more referring to a collective volume that coincides with its published introductory section, resulting in a total of 18 publications. At this point, it is worth stressing that other sources of finding literature could enrich this way of review, although our search results are a sufficient qualitative sample to distinguish the evolving trend over time.

Table 1. Analysis of 18 publications that have in their titles the terms "competitiveness" and "industrial policy" simultaneously

\begin{tabular}{|c|c|c|}
\hline Article title & Focal points & $\begin{array}{c}\text { Connection of industrial policy and } \\
\text { competitiveness }\end{array}$ \\
\hline $\begin{array}{l}\text { Trends of competitiveness } \\
\text { and industrial policy of Japan } \\
\text { in Southeast Asia (Sassoon, } \\
\text { 1976) }\end{array}$ & $\begin{array}{l}\text { Competitiveness results from cost advantages, } \\
\text { quality factors, trade performance, and others. } \\
\text { Industrial policy takes place in tandem with the } \\
\text { structural changes in the national economic } \\
\text { system. }\end{array}$ & $\begin{array}{l}\text { The competitiveness of specific industries } \\
\text { defines the overall national } \\
\text { competitiveness, and this } \\
\text { industrial-national system of } \\
\text { competitiveness has repercussions for the } \\
\text { national industrial policy and vice versa. }\end{array}$ \\
\hline $\begin{array}{l}\text { Competitiveness and } \\
\text { industrial policy (Tiemstra, } \\
\text { 1994) }\end{array}$ & $\begin{array}{l}\text { Competitiveness is the problem of "transitions } \\
\text { costs" from one industrial structure to another. It } \\
\text { is pointless to use industrial policies to hinder } \\
\text { structural changes since our world is } \\
\text { interconnected, and market forces are too } \\
\text { powerful. }\end{array}$ & $\begin{array}{l}\text { A country must not use its industrial policy } \\
\text { with subsidies to specific industries } \\
\text { because it ends up creating higher costs } \\
\text { and, therefore, intensifying the "problem" } \\
\text { of competitiveness. }\end{array}$ \\
\hline $\begin{array}{l}\text { Global competitiveness: } \\
\text { Industrial policy in the } \\
\text { performance of Asia and } \\
\text { Europe (Erber et al., 1997) }\end{array}$ & $\begin{array}{l}\text { The international competitiveness of firms refers } \\
\text { to specific industries and sectors of national } \\
\text { economies. A future-oriented industrial policy } \\
\text { must be creating the framework conditions } \\
\text { capable of helping the firms to adapt to the } \\
\text { changing environment by promoting research and } \\
\text { development, technical innovations, training, and } \\
\text { infrastructure. }\end{array}$ & $\begin{array}{l}\text { Industrial policy is a structural and } \\
\text { competition-oriented policy. }\end{array}$ \\
\hline $\begin{array}{l}\text { UK competitiveness policy } \\
\text { vs. Japanese industrial policy } \\
\text { (El-Agraa, 1997) }\end{array}$ & $\begin{array}{l}\text { Competitiveness policy means building an } \\
\text { environment capable of influencing all industries, } \\
\text { whether domestic or foreign. The old industrial } \\
\text { policy that favored industries of high growth } \\
\text { potential belongs to the past since it focuses now } \\
\text { on privatization and deregulation. }\end{array}$ & $\begin{array}{l}\text { Competitiveness policy is different from } \\
\text { industrial policy. }\end{array}$ \\
\hline $\begin{array}{l}\text { Introduction: Industrial policy } \\
\text { and technological } \\
\text { competitiveness (Hiraoka, } \\
\text { 1998) }\end{array}$ & $\begin{array}{l}\text { Globalization affects technological and industrial } \\
\text { competitiveness. When government policies } \\
\text { defend specific interest groups to empower } \\
\text { national/industrial competitiveness, they can } \\
\text { weaken an advanced nation's economy. }\end{array}$ & $\begin{array}{l}\text { In the age of globalization and the current } \\
\text { transition towards an "Information } \\
\text { Revolution" era, government policies of } \\
\text { industrial competitiveness enhancement } \\
\text { are useful only during "catch-up" periods } \\
\text { towards new technological and industrial } \\
\text { developments. }\end{array}$ \\
\hline $\begin{array}{l}\text { The industrial policy of } \\
\text { competitiveness: A review of } \\
\text { recent developments in the } \\
\text { UK (Wren, 2001) }\end{array}$ & $\begin{array}{l}\text { Competitiveness is equivalent to productivity } \\
\text { growth that provides national competitive } \\
\text { advantages. Industrial policy has a limited role } \\
\text { now and does not focus on redistribution } \\
\text { objectives but only on horizontal measures by } \\
\text { applying a more limited set of policy tools. }\end{array}$ & $\begin{array}{l}\text { The competitiveness policy of the UK, } \\
\text { designed under the influence of the new } \\
\text { economic theories on growth and trade, } \\
\text { differs from the UK's industrial policy, } \\
\text { which is only a subset of the } \\
\text { competitiveness policy. }\end{array}$ \\
\hline Best practice manufacture as & Competitiveness/industrial policy in the UK & The search for best practices in \\
\hline
\end{tabular}


industrial policy: Lean production, competitiveness and monopoly capitalism (Coffey, 2003)

Services-led industrial policy for inclusive growth and competitiveness (Hafeez Siddiqui \& Mujtaba Nawaz Saleem, 2010) focuses mostly on building a competitive advantage in the manufacturing sector via the method of "best-practices." manufacturing can distort the competitiveness/industrial policy in the UK by creating an environment attractive to "unchallenged transnational corporations" that may affect the interests of the workers and other communities.

A "services-led" industrial policy must lead to the structural transition of these Asian economies by attributing significance in improving competitiveness. competitiveness. The existing industrial policy status quo must match appropriately with the underlying economic structures, at least in these "services-led" economies.
EU industrial policy and competitiveness in rural SMEs (Bosworth et al., 2011)

The "Lisbon Agenda" goals of competitiveness do not consider the rural areas. EU's industrial policy that focuses on empowering SME innovation must create advantages for rural areas and small businesses.

Conceptualisations, relationships and trends between innovation, competitiveness, and development: Industrial policy beyond the crisis ( $\mathrm{P}$. Bianchi \& Labory, 2012)

Global policy developments towards industrial policy and skills: Skills for competitiveness and growth (Froy, 2013)

Introduction: Structural change, competitiveness and industrial policy (Da Silva \& Teixeira, 2014)

Do patterns of trade and international competitiveness support the case for industrial policy? (Haar, 2014)

The new European industrial policy: Global competitiveness and the manufacturing renaissance (Mosconi, 2015)

Competitiveness and
sustainability-A modern
economic approach to the
industrial policy (Popescu et
al., 2015)

Competitiveness and sustainability-A modern al., 2015)

The sustainability of competitiveness and
restructuring of firms need a new industrial policy. This "holistic" industrial policy must improve the firm's environment and the existing institutional framework.
The search for competitiveness within the industrial policy is not an aspect of direct intervention solely since the firms themselves must create competitive advantages and influence policymaking. Only a "holistic" industrial policy in the current conditions of crisis can sustain the competitiveness of firms by securing individual rights and building on new knowledge processes.
UK's "bottom-up" industrial policy focuses on improving local productivity and competitiveness. UK's industrial policy does not "invest in winners" but provides support to firms' networks

\begin{abstract}
"Skills policies" must be proactive to enhance productivity and growth while policymakers must invest in education at the local level.
\end{abstract} and helps them access required skills.

European periphery is facing a structural competitiveness problem because the industrial growth model of these nations is exhausted. Industrial policy constitutes a sum of policy tools to boost specific economic activities and propel structural changes.

Foreign trade performance reflects the international and industrial competitiveness of nations. The trends of international competitiveness based on international trade justify (or not) the need for industrial policies. EU can ameliorate its competitiveness and technology policy based on its current overarching policy. Europe needs both a new industrial policy and manufacturing to promote the required structural changes by finding out the right equilibrium between state intervention and market forces.

EU's "consolidated industrial policy" aims to
ensure a legal substructure to boost innovation
and human capital investment and access to
finance. Romania could sustain its global
competitiveness by implementing a "complex

This diminishing in value industrial growth model of these countries calls for a "multidimensional policy" that can build upon a sustainable trajectory of long-term productivity growth and international competitiveness.

Constructing a framework conducive to growth and innovation is probably more valuable for the industrial policy rather than targeting specific sectors. A new industrial policy can help Europe to improve in terms of global competitiveness.
Competitiveness and sustainability are the main driving forces behind a modern approach to industrial policy. 
industrial policy" headed towards the EU's

industrial policy objectives and priorities.

\begin{tabular}{|c|c|c|}
\hline $\begin{array}{l}\text { Industrial competitiveness in } \\
\text { MENA countries: Current } \\
\text { strategic directions of } \\
\text { industrial policy (Fernández } \\
\text { \& Pablo-Marti, 2016) }\end{array}$ & $\begin{array}{l}\text { Trade agreements in the Middle East and North } \\
\text { Africa countries propel industrial competitiveness } \\
\text { but also cause additional pressure to small } \\
\text { companies. These countries need new strategic } \\
\text { directions for their industrial policies. }\end{array}$ & $\begin{array}{l}\text { A new "industrial strategy" requires a } \\
\text { cross-sectoral analysis to favor the } \\
\text { development of a competitive industrial } \\
\text { sector. }\end{array}$ \\
\hline $\begin{array}{l}\text { Regional competitiveness in } \\
\text { the context of "new industrial } \\
\text { policy" - The case of Croatia } \\
\text { (Bačić \& Aralica, 2017) }\end{array}$ & $\begin{array}{l}\text { EU's smart specialization policy and strategy } \\
\text { influence Croatia's regional competitiveness. This } \\
\text { horizontal industrial policy emphasizes support at } \\
\text { the local level with industrial clusters and } \\
\text { business networks creation. }\end{array}$ & $\begin{array}{l}\text { This policy is going to affect the } \\
\text { competitiveness of Croatian regions by } \\
\text { supporting relevant national projects on } \\
\text { clusters of competitiveness. }\end{array}$ \\
\hline $\begin{array}{l}\text { Competitiveness and } \\
\text { industrial policy: From } \\
\text { rationalities of failure towards } \\
\text { the ability to evolve (Peneder, } \\
\text { 2017) }\end{array}$ & $\begin{array}{l}\text { Competitiveness is the socio-economic system's } \\
\text { "ability to evolve" by the rising of the long-term } \\
\text { standard of living. Industrial policy must aim at } \\
\text { empowering the broadly defined competitiveness } \\
\text { of the socio-economic system. }\end{array}$ & $\begin{array}{l}\text { Industrial policy and competitiveness form } \\
\text { a "dynamic rationale" deriving from the } \\
\text { multilevel "micro-meso-macro" } \\
\text { evolutionary perception and ontology, and } \\
\text { there is no dichotomy between sectoral } \\
\text { intervention and framework condition } \\
\text { policies. }\end{array}$ \\
\hline
\end{tabular}

The review of the literature leads us to the following conclusions about the combined evolution of competitiveness and industrial policy:

- Concerning the determinants and definitions of competitiveness, an emerging pattern is that it initiates analytically from partial rather than unified features, such as "cost advantages" or "trade performance." Throughout the examined period, another observable pattern is the relatively diminishing industrial character of competitiveness, meaning that the literature refers progressively less to the competitiveness of specific industries (vertical policies). Finally, a few studies of competitiveness tend (a) to equalize the concept with productivity growth, (b) to refer to a competitiveness policy capable of influencing all industries, (c) to discuss the competitiveness of firms and innovation (horizontal policies), and (d) to analyze competitiveness as an aspect of trans-regional and trans-national development (diagonal and integrated policies).

- The relation of industrial policy with the structural changes it causes in the national socio-economic system is the usual pattern in this literature. Industrial policy appears as an instrument that can deal with the structural changes occurring on a global scale. A significant part of the literature emphasizes the horizontal character of industrial policies that need not "invest in winners" and specific interest groups but to build a conducive environment for business innovation. A growing minority also stands on the aspect of empowering the SMEs, especially on a local scale, and on the fact that industrial policy needs to be nowadays a holistic policy, which must incorporate in practice the constant mutations happening at the entire socio-economic system (Aiginger, 2015).

- Initially, industrial policy was an instrument of favoring the competitiveness of specific industries, whereas today, it does not focus explicitly on direct industrial intervention since firms themselves must also create and sustain competitive advantages. Industrial policy over time seems to pose the goal of creating an environment conducive to broader social and economic innovation. A minority in the literature tends to distinguish between competitiveness policy and industrial policy by arguing mostly that industrial policy is probably a subset of the competitiveness policy. A recent observable pattern in the literature is that industrial policy acquires a repositioned perception and practice, analyzed as a new, holistic, multidimensional, or cross-sectoral and cross-social policy that can help to sustain the competitiveness of firms, industries, localities, nations, or other national agglomerations. Most significantly, and according to Peneder (2017), a "dynamic rationale" between competitiveness and industrial policy exists, in the sense that industrial policy must be an instrument that enhances the ability of the multilevel (micro-meso-macro) socio-economic system to evolve. 


\section{Searching for an Actual Integrated Industrial Policy}

From the last observations, namely that industrial policy must be an integrated practice of strengthening the multileveled competitiveness, several implications emerge. For example, the dimension of economic attractiveness of the socio-economic space seems to gain increasing interest, in the sense that attractiveness is the evolutionary capacity to receive, host and develop external economic resources and interests (Atkinson, 2012). In the integrated form of industrial policy, the creation of favorable conditions for attracting external investment potential is critical for all socio-economic systems, regardless of their level of competitiveness (Aghion et al., 2015).

From the relevant recent literature dealing with the issue of integratedness of industrial policy, we can identify some notable characteristics. For example, Ambroziak (2017) states that the primary pursuit of any modern industrial policy is the amelioration of the broadly perceived manufacturing sector by not focusing only on the traditional fabrication but also at the pre- and post-fabrication phases that also provide significant socio-economic benefits. Bianchi and Bianchi (2019) suggest the integrated form of industrial policy as a political instrument that balances between different streams and goals while Barrowclough and Kozul-Wright (2018) view this industrial policy as a complex set of interlinked and complementary policies.

Lauridsen (2018) suggests a new industrial policy for the $21^{\text {st }}$ century, where the "orthodox" policy agenda that focuses on value chain development is no longer efficient. On the contrary, a new orientation of industrial policies requires a cross-fertilization of more heterodox approaches that can help policymakers and scholars alike understand better the value chain dynamics and how industrial policies create competitive advantages on a local scale and contribute to the creation of jobs of higher quality.

Although such analyses have interpretive significance and introduce the integrated character of industrial policy, they do not introduce the primary goal of industrial policy; that is, stimulating the multileveled and systemic socio-economic competitiveness. Vlados (2019) somehow addresses this problem by introducing the concept of "Competitiveness Web" (Figure 1).

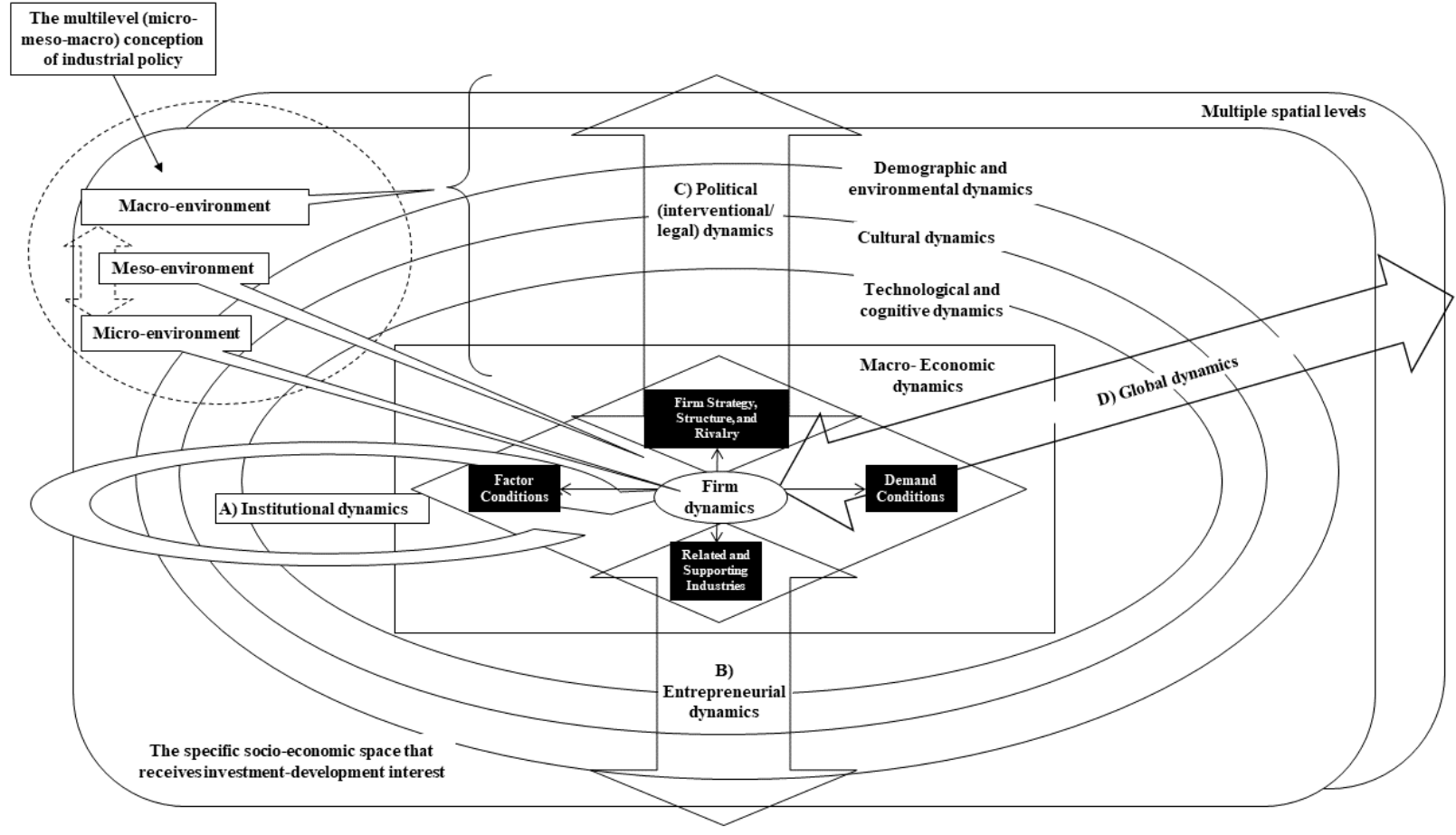

Figure 1. The competitiveness web, based on Vlados (2019)

The competitiveness web approach depicts the socio-economic system as a multilevel space of different dynamic subsystems. In this evolutionary conception, the micro-environment corresponds to the dynamics of the firm that lies 
at the center of the system, the meso-environment constitutes the dynamics of the broadly perceived industry that includes local and regional business ecosystems and clusters (Acs et al., 2017; Lazzeretti et al., 2014), while the macro-environment features the combined reproduction of technological, cultural and demographic dynamics. In this complete system, four structural spheres act as constant factors of readjustment and evolutionary adaptation: the institutional, entrepreneurial, political, and global dynamics.

A. The institutional "physiognomy" is the force that defines existing social and economic norms, which tend to remain unchanged for long periods.

B. Private entrepreneurship is the driving force behind the dynamics of innovation that affects and alters the system at all levels of space and for all actors.

C. The political intervention is the regulatory force that has an incessant and structural impact on the socio-economic system.

D. Global dynamics signifies the ubiquitous re-calibration of balances at a global level, as the different socio-economic systems (competitiveness webs) compete with one another to "impose" their attractiveness.

The question arising from this analysis is whether this theoretical framework of the competitiveness web could be used in the context of an integrated industrial policy.

First, the competitiveness web deepens Porter's diamond approach, which suggests that national competitiveness results from the evolutionary cluster dynamics at the levels of firm strategy-structure-rivalry, related-supporting industries, demand conditions, factor conditions. In this context, the competitiveness web could lead to the construction of a corresponding indicator that measures the competitiveness of the national socio-economic system by considering all the intersected levels of space.

Secondly, by providing measurable results, it could enable policymakers to focus on specific issues concerning the improvement of the performance of different subsystems, resulting in the overall enhancement of the national socio-economic system. In this context, the competitiveness web approach conceives a general outline of the integrated industrial policy, by also placing in the epicenter of development the activity and innovation of the firm.

As stressed by the literature, a more specific outline of this integrated industrial policy could concern policies at the micro and meso levels. Vlados and Chatzinikolaou (2019) suggest that a new policy for building robust business ecosystems starts primarily by improving the potential of the firm (in general, the socio-economic organization) that innovates and adapts by synthesizing the internal spheres of strategy, technology and management. The Stra.Tech.Man theoretical framework (strategy-technology-management synthesis) approaches the innovation creation of every socio-economic organization as a result of the answers it gives on a set of fundamental questions. Strategy corresponds to "where is the organization currently and where does it aspire to reach in the future," technology is about figuring out "how to create, use and disseminate the expertise of the organization," and the question that directs the management of the firm is "how does the organization make use of the available resources internally." The synthesis of these dimensions in the internal environment of the socio-economic organization determines the "physiological" boundaries, in the sense that firms are also "living organizations" that deal with constraints imposed by the co-evolving external and internal environment (Vlados, 2019a).

As it has been proven (Vlados, 2004), in this biological and evolutionary approach, business ecosystems become more or less competitive according to how advanced is the Stra.Tech.Man physiology of the domestic businesses. Therefore, the crucial element in the development of the multilevel socio-economic system is the way that its actors manage to innovate effectively. To this end, various policies to strengthen this local potential should be a priority for an integrated industrial policy (Figure 2). 


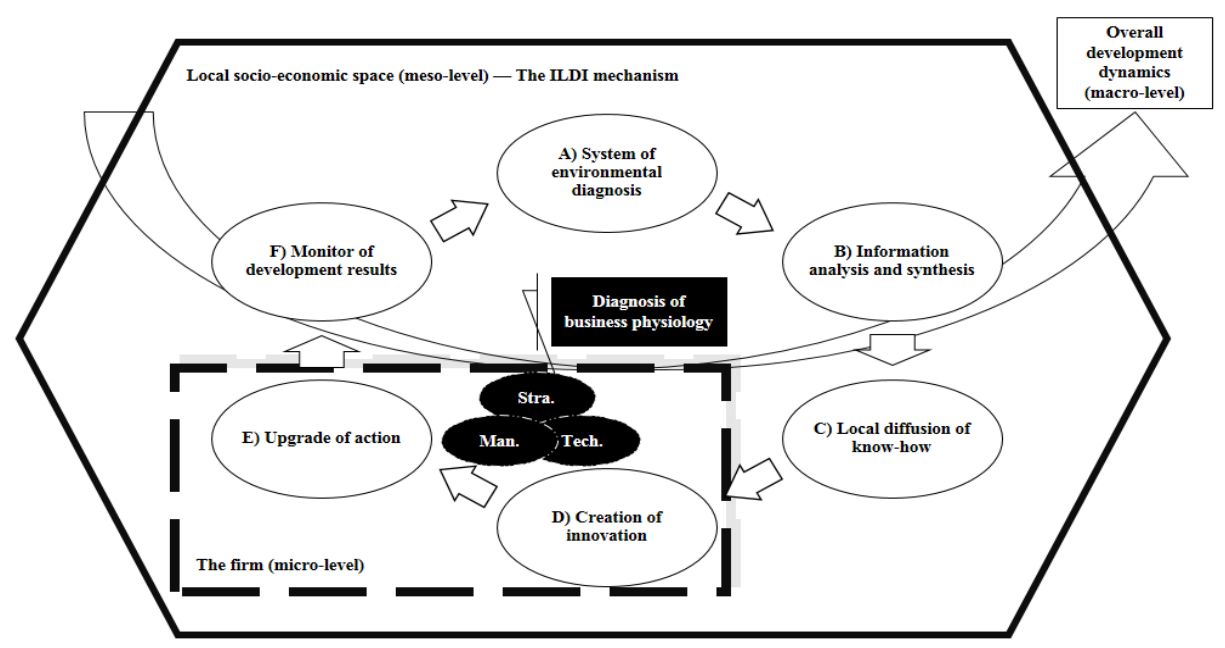

Figure 2. The Institute of Local Development and Innovation (ILDI) as a "business ecosystems" policy, based on Vlados and Chatzinikolaou (2019)

This micro- and meso-level policy is the Institutes of Local Development and Innovation (ILD), which could have as a final goal to enhance the innovation of the firm and, hence, to improve the overall competitiveness of the local business ecosystem by linking all the players that contribute locally in the creation of innovation. The ILDIs could follow a mechanism of six steps, which first could construct a system of diagnosing the potential of the external and internal environment. Second, it could process, analyze and synthesize related information. Third, it could attempt an initial diffusion of relevant expertise. Fourth, it could aim at enhancing innovation after diagnosing the Stra.Tech.Man potential of the specific firm. Fifth, it could provide consulting and entrepreneurial advice to the local firms in terms of upgrading their evolutionary physiology. Sixth, it could build a monitoring mechanism that observes and evaluates the developmental results.

Even though Vlados and Chatzinikolaou (2019) proposed this mechanism for the case of a less developed regional business ecosystem in Greece in order to be established upon effective linkages between the local government, academia and industry, this theoretical policy framework we think that it could be used as an industrial policy instrument and in other socio-economic systems. The main reason is that the relevant literature we have analyzed focuses on the proactive role of an integrated industrial policy towards the ways of enhancing competitiveness at the local and regional levels (Figure 3).

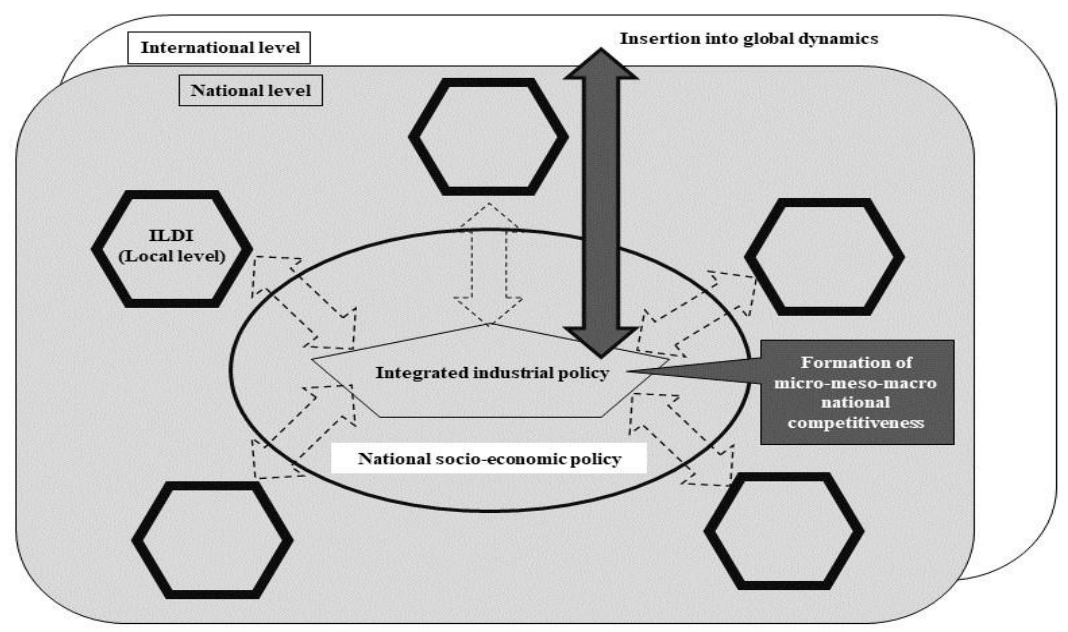

Figure 3. The complete theoretical framework of an integrated industrial policy that enhances multilevel competitiveness 
Finally, the complete theoretical framework we are proposing has, at its core, the perception that industrial policy is indeed integrated, as the creation of national competitiveness is the result of micro-meso-macro levels simultaneously. As part of the overall national socio-economic policy, a new industrial policy should focus on different micro-meso-level policies, which would no longer target specific sectors. The new and integrated industrial policy must be focusing on the ability of business ecosystems to innovate, be more competitive and adapt to the changing environmental conditions and the dynamics of globalization.

\section{Conclusions, Limitations and Discussion}

This article investigated the co-evolution of the concepts of competitiveness and industrial policy and highlighted their current mutating trends. It also emphasized their attempts of synthesis by distinguishing a set of corresponding publications and reviewing them from an integrative perspective and methodology. Our goal in this qualitative and non-systematic literature review was to synthesize these elements and construct a new theoretical framework. Future studies could attempt a more systematic bibliographic overview, possibly by conducting a bibliometric analysis to find out more in-depth trends in the evolution of these two terms and combining qualitative and quantitative components (Ellegaard \& Wallin, 2015). However, our analysis bears some implications at the level of policymaking and can advance our knowledge in the combined evolution of competitiveness and industrial policy.

We initially found that the conception of competitiveness is heading towards a multilevel perception since the literature discusses competitiveness at all the possible structured levels. At the same time, industrial policy is no longer a means of subsidizing specific industries, neither only a limited set of policy instruments to build an environment clear of intervention. Industrial policy is an intervention comprising compound vertical and horizontal elements and having a diagonal and transversal reach. By strengthening the multilevel micro-meso-macro competitiveness, an integrated industrial policy could enhance the ability of the socio-economic systems to adapt in the changing conditions of globalization, especially after the COVID-19 pandemic which accelerates the emergence of a new and restructured phase of globalization (Andrikopoulos \& Nastopoulos, 2015; Vlados et al., 2019).

The gradual exhaustion of the prospects of the incremental innovation (Vlados, 2019c)-mainly from the perspective of multinational companies - and with the power acquired by the "fast second" (Markides \& Geroski, 2004) in an environment of rapid change and informatization (Pastré, 1982), lead unavoidably to a repositioned perspective. Policymakers now need to realize that innovation and technology are phenomena that cross multiple industries and levels of economic activity. In today's era of crisis and restructuring of globalization, a new industrial policy must combine both horizontal and vertical interventions. In this sense, industrial policymaking must not aim to create a field clear of intervention for the players or to intervene vertically towards large industries, but to select always the "best" way of policy. Besides, this selective intervention must be accelerated in the emerging fourth industrial revolution because future industries can only be small today, but with significant innovative prospects (Kelly, 2019).

On this basis, the article proposed a systemic framework of competitiveness conception in the form of a competitiveness web, in which the multiple socio-economic subsystems interact with each other through closely interlinked evolutionary processes. The Competitiveness Web approach places the dynamics of the firm centrally (micro-level), the industrial dynamics at the meso-level, and perceives the macro-dynamics as an overarching organic developmental aggregation.

The policy proposal put forward in this article is that the overall "super-system" of the competitiveness web is ultimately a possible methodological tool for an integrated industrial policy, which must be able to also act as a "nursery" for micro-meso policies that can empower the local socio-economic systems. To this end, the Institutes of Local Development and Innovation (ILDI) could constitute an integral part of an integrated national industrial policy. This integrated industrial policy needs probably to be high in the agenda of every national socio-economic policy to enhance the multilevel competitiveness and to direct the insertion of the national socio-economic system into the global dynamics in a more equilibrated and sustainable way.

In aggregated terms, the new theoretical framework and dimensions resulting from this study are as follows:

i. First, there is an explicit link between competitiveness development and industrial policy.

ii. Competitiveness results necessarily from all levels of the socio-economic system (micro-meso-macro), and an integrated industrial policy must be able to strengthen competitiveness horizontally, vertically and diagonally at the same time.

iii. The framework of the competitiveness web can be used in the development of an integrated industrial policy as it not only focuses on industrial dynamics (such as Porter's diamond) but taxonomizes all the components of the socio-economic system, placing business innovation at the center. 
iv. The integrated industrial policy must be able to strengthen the different local and regional business ecosystems. The ILDI policy through the diagnosis and enhancement of Stra.Tech.Man physiology (strategy-technology-management synthesis) is moving in this direction.

v. The integrated industrial policy and competitiveness are elements of adaptability to the dynamics of globalization.

\section{Acknowledgments}

We would like to express our gratitude to Dr. Andreas Andrikopoulos, Associate Professor at the Department of Business Administration of the University of the Aegean, who provided useful comments during the writing of this manuscript.

\section{References}

Acemoglu, D., \& Robinson, J. A. (2012). Why nations fail: The origins of power, prosperity, and poverty. New York: Crown Publishers. https://doi.org/10.1355/ae29-2j

Acs, Z. J., Stam, E., Audretsch, D. B., \& O'Connor, A. (2017). The lineages of the entrepreneurial ecosystem approach. Small Business Economics, 49(1), 1-10. https://doi.org/10.1007/s11187-017-9864-8

Aghion, P., Akcigit, U., \& Howitt, P. (2015). The Schumpeterian growth paradigm. Annual Review of Economics, 7(1), 557-575. https://doi.org/10.1146/annurev-economics-080614-115412

Aiginger, K. (2015). Industrial policy for a sustainable growth path. In D. Bailey, K. Cowling, \& P. Tomlinson (Eds.), New Perspectives on Industrial Policy for a Modern Britain (pp. 364-394). Oxford, UK: Oxford University Press. https://doi.org/10.1093/acprof:oso/9780198706205.003.0019

Ajitabh, A., \& Momaya, K. (2004). Competitiveness of firms: Review of theory, frameworks and models. Singapore Management Review, 26(1), 45-61.

Ambroziak, A. A. (2017). A theoretical concept of a modern industrial policy. In A. A. Ambroziak (Ed.), The New Industrial Policy of the European Union (pp. 173-186). Cham, Switzerland: Springer International Publishing. https://doi.org/10.1007/978-3-319-39070-3_7

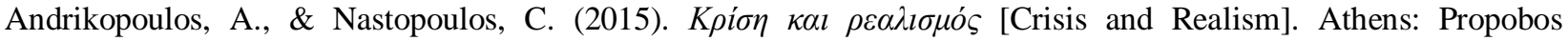
Publications.

Atkinson, R. (2012). Urban governance and competitiveness: Improving 'urban attractiveness.' In B. Egner, M. Haus, \& G. Terizakis (Eds.), Regieren: Festschrift für Hubert Heinelt (pp. 297-312). Wiesbaden: VS Verlag für Sozialwissenschaften. https://doi.org/10.1007/978-3-531-19793-7_17

Bačić, K., \& Aralica, Z. (2017). Regional competitiveness in the context of "New industrial policy" - The case of Croatia. Zbornik Radova Ekonomskog Fakultet Au Rijeci, 35(2), 551-582. https://doi.org/10.18045/zbefri.2017.2.551

Balkytè, A., \& Tvaronavičienè, M. (2010). Perception of competitiveness in the context of sustainable development: Facets of "sustainable competitiveness." Journal of Business Economics and Management, 11(2), 341-365. https://doi.org/10.3846/jbem.2010.17

Barrowclough, D. V., \& Kozul-Wright, R. (2018). Integrated industrial policy. In M. A. Yülek (Ed.), Industrial Policy and Sustainable Growth (pp. 51-68). Singapore: Springer Singapore. https://doi.org/10.1007/978-981-10-5741-0_14

Bianchi, A., \& Bianchi, P. (2019). Keeping Emilia-Romagna strong: An integrated industrial policy approach. Wirtschaftsdienst, 99(1), 65-70. https://doi.org/10.1007/s10273-019-2434-8

Bianchi, P., \& Labory, S. (2012). Conceptualisations, relationships and trends between innovation, competitiveness and development: Industrial policy beyond the crisis. In P. Cooke, M. D. Parrilli, \& J. L. Curbelo (Eds.), Innovation, Global Change and Territorial Resilience (pp. 295-312). Cheltenham, UK; Northampton, MA: Edward Elgar.

Bobba, F., Langer, W., \& Pous, J. (1971). Bericht über die Wettbewerbsfähigkeit der Europäischen Gemeinschaf [Report on the competitiveness of the European Community]. Brussels, Belgium: Gemeinschaft

Bosworth, G., Dana, L. P., \& McElwee, G. (2011). EU industrial policy and competitiveness in rural SMEs. International Journal of Entrepreneurship and Small Business, 14(3), 391-405. https://doi.org/10.1504/IJESB.2011.042760 
Boyer, R., \& Durand, J.-P. (1993). L'après-Fordisme. Paris: Syros.

Chang, H.-J. (2010). Industrial policy: Can we go beyond an unproductive confrontation? (2010/1; Working Papers). Turkish Economic Association.

Cho, D.-S., \& Moon, H.-C. (2000). From Adam Smith to Michael Porter: Evolution of competitiveness theory. New Jersey; London; Singapore; Hong Kong: World Scientific. https://doi.org/10.1142/4531

Coffey, D. (2003). Best practice manufacture as industrial policy: Lean production, competitiveness and monopoly capitalism. In D. Coffey \& C. Thornley (Eds.), Industrial and Labour Market Policy and Performance: Issues and Perspectives (pp. 45-61). London, UK: Routledge.

D'Andrea, T. (1992). Who's bashing whom: Trade conflict in high technology industries. Washington DC, US: Institute for International Economics.

Da Silva, E. G., \& Teixeira, A. A. C. (2014). Introduction: Structural change, competitiveness and industrial policy. In A. A. C. Teixeira, E. G. Da Silva, \& R. P. Mamede (Eds.), Structural Change, Competitiveness and Industrial Policy: Painful Lessons from the European Periphery (pp. 3-9). London, UK; New York, US: Routledge.

Dopfer, K., Foster, J., \& Potts, J. (2004). Micro-meso-macro. Journal of Evolutionary Economics, 14(3), 263-279. https://doi.org/10.1007/s00191-004-0193-0

Dunning, J. H. (1993). Internationalizing Porter's diamond. Management International Review; Wiesbaden, 33(2), 7-15.

El-Agraa, A. M. (1997). UK Competitiveness Policy vs. Japanese Industrial Policy. The Economic Journal, 107(444), 1504-1517. https://doi.org/10.1111/j.1468-0297.1997.tb00061.x

Ellegaard, O., \& Wallin, J. A. (2015). The bibliometric analysis of scholarly production: How great is the impact?. Scientometrics, 105(3), 1809-1831. https://doi.org/10.1007/s11192-015-1645-z

Erber, G., Hagemann, H., \& Seiter, S. (1997). Global competitiveness: Industrial policy in the performance of Asia and Europe. Journal of Contemporary Asia, 27(3), 338-355. https://doi.org/10.1080/00472339780000201

Esser, K., Hillebrand, W., Messner, D., \& Meyer-Stamer, J. (2013). Systemic competitiveness: New governance patterns for industrial development. London, UK: Routledge. https://doi.org/10.4324/9781315036465

Falck, O., Gollier, C., \& Woessmann, L. (2011). Industrial Policy for National Champions. Cambridge, MA: MIT Press. https://doi.org/10.7551/mitpress/9780262016018.001.0001

Fernández Fernández, M. T., \& Pablo-Marti, F. (2016). Industrial competitiveness in MENA countries: Current strategic directions of industrial policy. In M. Erdodu \& B. Christiansen (Eds.), Handbook of Research on Comparative Economic Development Perspectives on Europe and the MENA Region (pp. 152-171). Hershey, PA, US: IGI Global. https://doi.org/10.4018/978-1-4666-9548-1.ch008

Fischer, A. M. (2015). The end of peripheries? On the enduring relevance of structuralism for understanding contemporary global development. Development and Change, 46(4), 700-732. https://doi.org/10.1111/dech.12180

Froy, F. (2013). Global policy developments towards industrial policy and skills: Skills for competitiveness and growth. Oxford Review of Economic Policy, 29(2), 344-360. https://doi.org/10.1093/oxrep/grt020

Garelli, S. (2006). Top class competitors: How nations, firms, and individuals succeed in the new world of competitiveness. Chichester, US; Hoboken, NJ: John Wiley \& Sons.

Haar, L. N. (2014). Do patterns of trade and international competitiveness support the case for industrial policy?. Policy Studies, 35(3), 221-245. https://doi.org/10.1080/01442872.2014.886680

Hafeez Siddiqui, S., \& Mujtaba Nawaz Saleem, H. (2010). Services-led industrial policy for inclusive growth and competitiveness. Competitiveness Review, 20(2), 166-181. https://doi.org/10.1108/10595421011029875

Herciu, M., Ogrean, C., \& Belascu, L. (2011). Leveraging tangible and intangible assets by using a possible firm competitiveness index. Global Business and Economics Review, 14(1-2), 115-124. https://doi.org/10.1504/GBER.2012.044480

Hiraoka, L. S. (1998). Introduction: Industrial policy and technological competitiveness. International Journal of Technology Management, 15(6-7), 523-525. https://doi.org/10.1504/IJTM.1998.002629

Hodgson, G. (1994). Precursors of modern evolutionary economics: Marx, Marshall, Veblen, and Schumpeter. In R. England (Ed.), Evolutionary concepts in contemporary economics (pp. 9-35). Ann Arbor, MI: The University of 
Michigan Press.

Irwin, D. A. (2004). The aftermath of Hamilton's “Report on Manufactures.” The Journal of Economic History, 64(3), 800-821. https://doi.org/10.1017/S0022050704002979

Kelly, R. (2019). Constructing leadership 4.0: Swarm leadership and the Fourth Industrial Revolution. Cham, Switzerland: Springer International Publishing. https://doi.org/10.1007/978-3-319-98062-1

Krueger, A. O. (1990). Government failures in development. The Journal of Economic Perspectives, 4(3), 9-23. https://doi.org/10.1257/jep.4.3.9

Krugman, P. (1994). Competitiveness: A dangerous obsession. Foreign Affairs, 73(2), $28-44$. https://doi.org/10.2307/20045917

Krugman, P. (1996). Making sense of the competitiveness debate. Oxford Review of Economic Policy, 12(3), 17-25.

Krugman, P., \& Obstfeld, M. (1991). International economics: Theory and policy. New York, US: HarperCollins. https://doi.org/10.1093/oxrep/12.3.17

Lall, S. (2004). Reinventing Industrial Strategy: The role of government policy in building industrial competitiveness (No. 28; G-24 Discussion Papers). United Nations Conference on Trade and Development.

Lauridsen, L. S. (2018). New economic globalization, new industrial policy and late development in the 21st century: A critical analytical review. Development Policy Review, 36(3), 329-346. https://doi.org/10.1111/dpr.12299

Lazzeretti, L., Sedita, S. R., \& Caloffi, A. (2014). Founders and disseminators of cluster research. Journal of Economic Geography, 14(1), 21-43. https://doi.org/10.1093/jeg/lbs053

Markides, C., \& Geroski, P. (2004). Fast second: How smart companies bypass radical innovations to enter and dominate new markets. San Francisco, CA.: Jossey-Bass.

Mbate, M. (2016). Structural change and industrial policy: A case study of Ethiopia's leather sector. Journal of African Trade, 3(1), 85-100. https://doi.org/10.1016/j.joat.2017.01.001

Mosconi, F. (2015). The new European industrial policy: Global competitiveness and the manufacturing renaissance. London, UK; New York, US: Routledge. https://doi.org/10.4324/9781315761756

Naudé, W. (2010). Industrial policy: Old and new issues (Working Paper No. 2010, 106). World Institute for Development Economics Research.

OECD. (1975). Objectives and Instruments of Industrial Policy: A Comparative Study. Paris: OECD.

OECD. (2009). Competition policy, industrial policy and national champions. Roundtable on Competition Policy, Industrial Policy and National Champions. Global Forum on Competition. Retrieved from https://www.oecd.org/daf/competition/44548025.pdf

Pack, H. (1993). Productivity and industrial development in sub-Saharan Africa. World Development, 21(1), 1-16. https://doi.org/10.1016/0305-750X(93)90133-T

Pack, H. (2000). Industrial Policy: Growth Elixir or Poison?. The World Bank Research Observer, 15(1), 47-67. https://doi.org/10.1093/wbro/15.1.47

Pack, H., \& Saggi, K. (2006). Is There a Case for Industrial Policy? A Critical Survey. The World Bank Research Observer, 21(2), 267-297. https://doi.org/10.1093/wbro/lk1001

Pastré, O. (1982). Informatisation et emploi: Un survey. Revue d'économie industrielle, 21(1), 126-136. https://doi.org/10.3406/rei.1982.2066

Peneder, M. (2017). Competitiveness and industrial policy: From rationalities of failure towards the ability to evolve. Cambridge Journal of Economics, 41(3), 829-858. https://doi.org/10.2139/ssrn.2714941

Pollak, F., Svetozarovova, N., \& Malinak, B. (2018). Multifactor analysis of online reputation as a tool for enhancing competitiveness of selected tourism entities. Global Business and Economics Review, 20(2), 231-247. https://doi.org/10.1504/GBER.2018.090074

Popescu, V. A., Popescu, G. N., \& Popescu, C. R. (2015). Competitiveness and sustainability - a modern economic approach to the industrial policy. Metalurgija, 54(2), 426-428.

Porter, M. (1990). The competitive advantage of nations. New York: Free Press. https://doi.org/10.1007/978-1-349-11336-1

Raffaelli, R., \& Glynn, M. A. (2015). Institutional Innovation: Novel, Useful, and Legitimate. In C. Shalley, M. A. 
Hitt, \& J. Zhou (Eds.), The Oxford Handbook of Creativity, Innovation, and Entrepreneurship (pp. 407-420). Oxford, UK: Oxford University Press.

Robinson, J. A. (2009). Industrial policy and development: A political economy perspective. 2009 World Bank ABCDE Conference, Seoul.

Rodrik, D. (2004). Industrial Policy for the Twenty-First Century (KSG Working Paper No. RWP04-047). Harvard University. https://doi.org/10.2139/ssrn.617544

Rodrik, D. (2008). Normalizing Industrial Policy (Commission on Growth and Development Working Paper No. 3). World Bank.

Sassoon, J. (1976). Trends of competitiveness and industrial policy of Japan in southeast Asia. Lo Spettatore Internazionale, 11(3), 249-273. https://doi.org/10.1080/03932727608459075

Scott, B. R., \& Lodge, G. C. (1985). U.S. competitiveness in the world economy. The International Executive, 27(1), 26-26. https://doi.org/10.1002/tie.5060270112

Siudek, T., \& Zawojska, A. (2014). Competitiveness in the economic concepts, theories and empirical research. Acta Scientiarum Polonorum. Oeconomia, 13(1), 91-108.

Snyder, H. (2019). Literature review as a research methodology: An overview and guidelines. Journal of Business Research, 104, 333-339. https://doi.org/10.1016/j.jbusres.2019.07.039

The Global Competitiveness Report 2017-2018. (2017). World Economic Forum.

Tiemstra, J. P. (1994). Competitiveness and Industrial Policy. International Journal of Social Economics, 21(8), 30-42. https://doi.org/10.1108/03068299410065403

Torfing, J., Peters, B. G., Pierre, J., \& Sørensen, E. (2012). Horizontal, vertical, and diagonal governance. Oxford, New York: Oxford University Press. https://doi.org/10.1093/acprof:oso/9780199596751.003.0006

Tyson, L., \& Zysman, J. (1983). American Industry in International Competition: Government Policies and Corporate Strategies. California Management Review, 25(3), 27-52. https://doi.org/10.2307/41165015

Vlados, Ch. (2004). La dynamique du triangle stratégie, technologie et management: L'insertion des entreprises grecques dans la globalisation [Thèse de doctorat de Sciences Économiques, Université de Paris X-Nanterre]. Retrieved from http://www.theses.fr/2004PA100022

Vlados, Ch. (2019a). Change management and innovation in the "living organization": The Stra.Tech.Man approach. Management Dynamics in the Knowledge Economy, 7(2), 229-256. https://doi.org/10.25019/MDKE/7.2.06

Vlados, Ch. (2019b). Porter's diamond approaches and the competitiveness web. International Journal of Business Administration, 10(5), 33-52. https://doi.org/10.5430/ijba.v10n5p33

Vlados, Ch. (2019c). The phases of the postwar evolution of capitalism: The transition from the current crisis into a new worldwide developmental trajectory. Perspectives on Global Development and Technology, 18(4), 457-488. https://doi.org/10.1163/15691497-12341528

Vlados, Ch., \& Chatzinikolaou, D. (2019). Business ecosystems policy in Stra.Tech.Man terms: The case of the Eastern Macedonia and Thrace region. Journal of Entrepreneurship, Management and Innovation, 15(3), 163-197. https://doi.org/10.7341/20191536

Vlados, Ch., \& Chatzinikolaou, D. (2020). The competitiveness puzzle: Interpretations, misunderstandings, and conceptual reorientations towards integrated competitiveness policy approaches. Journal of Economics Bibliography, 7(1), 1-22. https://doi.org/10.1453/jeb.v7i1.2020

Vlados, Ch., Deniozos, N., \& Chatzinikolaou, D. (2019). Global crisis and restructuring: Theory, analysis, and the case of Greece. KSP Books. https://doi.org/10.2139/ssrn.3433099

Warwick, K. (2013). Beyond Industrial Policy: Emerging Issues and New Trends (OECD Science, Technology and Industry Policy Papers No. 2). Paris: OECD Publishing.

Wren, C. (2001). The industrial policy of competitiveness: A review of recent developments in the UK. Regional Studies, 35(9), 847-860. https://doi.org/10.1080/00343400120090266

Yao, D. A. (1988). Beyond the reach of the invisible hand: Impediments to economic activity, market failures, and profitability. Strategic Management Journal, 9(S1), 59-70. https://doi.org/10.1002/smj.4250090707 